\title{
ARAŞTIRMA
}

\section{INABILITY TO SPEAK: A QUALITATIVE STUDY ON THE EXPERIENCES OF PATIENTS WHO UNDERWENT PARTIAL LARYNGECTOMY*}

\author{
Ayla GÜRSOY** Melek ERTÜRK*** Nuray DEMİRCİ GÜNGÖRDÜ****
}

Alınıș Tarihi: 16.06.2016

Kabul Tarihi: 20.09.2016

\begin{abstract}
Objective: This study aims to determine the experiences of patients with partial laryngectomy related inability to speak.

Methods: The study followed purposeful sampling and saturation principles in which 10 patients with partial laryngectomy were included. The data were collected using "semi-structure interview method" and the data were analyzed by thematic analysis.

Results: Three themes were determined: perception of inability to speak, problems caused by inability to speak and communication methods. The patients explained that the inability to speak was like vanishing and that it caused them to experience loss of self-confidence. They explained that they again felt the happiness and joy of living when they began to speak again and that they felt themselves empowered. Problems caused by inability to speak were related to the difficulty to express physical needs, experience of negative feelings and social isolation. It was found out that patients used writing most in order to communicate with others but they did not find written communication effective to express them.

Conclusions: After laryngectomy, patients perceived inability to verbally speak as an important loss. Inability to speak causes inability to express their needs, experience of negative feelings and social isolation among the patients. Written communication method, used most to communicate, falls short in many aspects.
\end{abstract}

Keywords: Partial laryngectomy; verbal communication; psychosocial problems; nursing care

$\ddot{O Z Z T}$

Konuşamamak: Parsiyel Larenjektomi olan Hastaların Deneyimlerine İlişkin Kalitatif Bir Çalışma

Amaç: Çalışma parsiyel larenjektomi olan hastaların konuşamama nedeni ile yaşadıkları deneyimleri belirlemeyi amaçlamaktadır.

Yöntem: Çalışmaya amaçlı örnekleme yöntemine ve doygunluk ilkelerini bağll olarak 10 parsiyel larenjektomi olan hasta dâhil edildi. Veriler "yarı yapılandırılmış görüşme yöntemi”" kullanılarak toplandı ve "tematik analize" göre analiz edildi.

Bulgular: Konuşamama algısı, konuşamamanın neden olduğu problemler ve iletişim metotlarl olmak üzere üç tema belirlendi. Hastalar konuşamamanın yok olmak gibi olduğunu ve bu durumun öz güven kaybı yaşamalarına yol açtığını ifade ettiler. Tekrar konuşmaya başladıkları zaman ise hastalar mutluluk ve yeniden yaşama sevinci duyduklarını ve kendilerini güçlenmiş hissettiklerini ifade ettiler. Fiziksel ihtiyaçları açıklamada güçlük, negatif duygular yaşama ve sosyal izolasyon konuşamama nedeniyle yaşanılan problemlerdir. Hastaların iletişim için en çok yazmayı kullandıkları ancak yazarak iletişimi kendilerini ifade edebilmelerinde etkili bulmadıkları belirlendi.

Sonuçlar: Larenjektomi sonrası hastalar sözel iletişim kuramamayı önemli bir kayıp olarak algılamaktadırlar. Konuşamama hastaların ihtiyaçlarını açıllayamamasına, negatif duygular yaşamalarına ve sosyal izolasyona neden olmaktadır. Yazarak iletişim en çok kullanılan iletişim metodu ancak iletişim için yeterli değildir.

Anahtar kelimeler: Parsiyel larenjektomi; sözel iletişim; psikososyal problemler; hemşirelik bakımı

\section{INTRODUCTION}

Today, laryngeal cancer is one of the commonly seen and important health problems. Laryngeal cancer makes up $2-5 \%$ of whole body malignancies and $25 \%$ of head and neck malignancies (Ozudogru and Kaya 2006; Ozlugedik and Unal 2005).

After laryngectomy, many patients experience physical and psychosocial problems that affect their quality of life significantly (Evitts, Kasapoglu, Demirci and Miller 2011;

\footnotetext{
* This study was presented as a verbal at 13. Surgical Nursing Congress.

** Karadeniz Tech. Univ. Faculty of Health Sciences, Trabzon

*** Karadeniz Tech.Univ. Institute of Health Sciences, Trabzon e-posta melekerturk@ktu.edu.t

**** Recep Tayyip Erdogan University, School of Health, Department of Fundamentals of Nursing, Rize 
Abendstein, Nordgren, Boysen, Jannert, Silander, Ahlner-Elmqvist et al. 2005; Semple, Sullivan, Dunwoody and Kernohan 2004). Because of the treatment affect both the structure and function of this area, especially in terms of swallowing, breathing and speaking (Sammut, Ward and Patel 2014; Semple, Dunwoody, Kernohan and McCaughan 2009). It was determined that those patients who underwent partial laryngectomy also experienced a decrease in their life quality due to the change that occurred in their voice although their situation was better than those patients who underwent total laryngectomy (Hebel, Mantsopoulos and Bohr 2014; Philippe, Espitalier, Durand, Ferron, Bardet and Malard 2014; Webster, Samlan, Jones, Bunton and Tufano 2010)

Loss of the speech function is the primary negative result caused by laryngectomy (Ozlugedik and Unal 2005; Singer, Merbach, Dietz and Schwarz 2007; Tas, Yagiz, Karasalihoglu, Koten, Adalı and Uzun 2004). Patients undergo communicational problems with their family members and health care professionals after operation due to the inability to speak (Evitts, Kasapoglu, Demirci and Miller 2011). That individuals become dependent on others -especially in diseases- renders communication more important because inability to communicate increases dependency levels, causes the patients to feel useless and prevents them from performing self-care needs and thus may affect the recovery negatively (Happ 2000; Happ, Roesch and Kagan 2004).On the other hand, those who experience communicational difficulties are not only patients themselves but also health care professionals. Remarks and comments based on estimations and prejudices about non verbal behaviors of the patients limit the communication of the health care professionals very much and may cause them to make wrong decisions (Uyer 2000). Particularly when the nurse, who spends much time with the patient, is unable to communicate, she is seen as indifferent and thus the patient's confidence in nurses is lost (Howren, Christensen, Karnell and Funk 2010; Alasad and Ahmad 2005).

Perception of inability to communicate among the patients with laryngeal cancer, their communicational needs and communicational methods used are not taken into consideration enough (Uyer 2000). Inability to communicate with both health care professionals and patient's significant others and being indifferent to these problems lead to such feelings as anger, helplessness and fury; increase the stress levels and anxiety (Alasad and Ahmad 2005). Therefore, a patient-centered communication is to be maintained with patients who undergo partial laryngectomy. Because patient-centered communication includes eliciting and understanding the patient's perspective, concerns, needs, feelings, and functioning and offers patients and their family the opportunity to participate in the conversation (Epstein, Franks, Fiscella, Shields, Meldrum, Kravitz et al. 2005).

Treatment and care of the patients with laryngeal cancer requires a multidisciplinary team who is trained in physical and psychosocial rehabilitation. In this multidisciplinary team; the nurse occupies a special position so that the patient can finish his disease experience in health system in the shortest time possible and with minimal negative outcomes. If the nurse is able to appreciate the meaning and problems of loss of communication from the patients' perspectives; she may design effective solution methods.

There are sources that emphasize that patients with permanent or temporal loss of speaking ability after laryngectomy cannot make verbal communication and thus experience problems. However; the number of the studies that discover how patients' inability to make verbal communication affects their feelings and ideas and what kind of problems they have is very limited. Learning patients' these experiences with their own words and statements will make significant contributions so that health care personnel can understand what patients experience better and find effective solutions to their problems. This study aimed to explore what the patients who could not speak after partial laryngectomy experienced owing to inability to communication. It was thus aimed to determine the psychosocial, information and support needs of patients who underwent partial laryngectomy.

\section{METHOD}

The place and time of the study: The study was conducted between August 2011- June 2012 in a university hospital in Trabzon.

Study Sample: The criterion sampling as a type of purposeful sampling was utilized in the study. The basic understanding in the criterion sampling is to sample those who meet a series of preset criteria (Yildirım and Simsek 2013). In this context, those volunteers who underwent partial laryngectomy in the last two years in the hospital that we carried out our study, who was able to 
speak after they were discharged, and who had no psychiatric disease or treatments were included in the study. The criterion of having laryngectomy in the last two years was due to the possibility that patients would forget their experiences. In qualitative studies, it is not exactly possible to determine the sample size in advance. Sample size is determined by the saturation point (Higginbottom 2004). In this context, a researcher continues to collect data until the stage when the concepts and processes which can be the answers of a study question begin to repeat themselves (until the researcher reaches the point of saturation) (Yıldirım and Simsek 2013). In commitment to this principle, the sample size of the study was continued until the researcher reached the point of saturation in the data that were collected, and a total of 10 patients who had partial laryngectomy were interviewed.

From the hospital records, those patients who were determined to meet the study criteria were called by phone, informed about the study and their consents were obtained for making an interview. Interviews were held in a quiet room located in the outpatient clinic of otorhinolaryngology department of the hospital, by the first researcher of this study, who has received sufficient training in qualitative studies, and recorded in a voice recording device. Data were collected through semi-structured questions during these interviews. The semi-structured questions are below:

- What did you experience when you noticed your inability to speak on the day you underwent the surgery?

What did you feel?

What did you think?

What did you feel and think when you began to speak again?

- How did the inability to speak affect you?

How did the inability to speak influence the thoughts about yourselves?

How did the inability to speak influence the relationships with your environment?

What was the difficulties that you experienced in connection with the inability to speak?

- What were the methods that you used to establish communication with your environment in the period when you were unable to speak?

What were the communication methods that you used?

What was the most effective communication method?

What was the disadvantages of the communication methods used?
The time periods of the interviews with the patients change between 20 and 40 minutes. Each interview was coded so that only the researcher could know the persons who participated. Participants were assured of confidentiality, and pseudonyms were used.

Data analysis: The data were analyzed using the thematic analysis approach of Braun and Clarke (2006). Thematic analysis is a method of analysis used to report, analyze and determine the themes in data. Based on this method, the data obtained from the interviews were put down on paper, read again and again, and first opinions were noted. Peculiar characteristics of the data were systematically coded next to all the data sets and the related data were blended for each code. The related themes were determined based on these codes. The codes obtained from the data were checked, and a map was created for analysis. When the analysis was going on, specific designations and definitions were made for each theme and finally the reporting transaction regarding this information was carried out.

In order to check the reliability of the findings, two researchers carried out data analysis independently from each other. Then the themes formed by the researchers were compared. In case of differences in analysis, topics were identified after reaching a agreement. Ethical Consideration: Approval of Ethics Committee for Clinical Researches was obtained. Also, permissions from the management of the hospital where patients were operated were obtained in order to get contact information of the patients. A written approval was also received from the patients regarding their volunteered participation in the study.

Study Limitations: As we had no female patients that underwent partial laryngectomy within the time period that our study was carried out, the study was made only with male patients. As females and males might have different perspectives about such experiences, similar studies including female patients might produce different results. Besides, as the study was made with those patients who temporarily lost their ability to establish communication by speech, the results do not cover those patients who lose this ability permanently.

\section{FINDING AND DISCUSSION}

All of the participants were male and their mean age was $59.4 \pm 8,9$ years. The period in which patients could not speak after laryngectomy was between 8 and 47 days. Three 
main themes were determined in the study. These are: the perception of the inability to speak, the problems caused by the inability to speak and communication methods

\section{Theme 1: Perception of inability to speak}

The patients explained that the inability to speak is like death, and that they felt themselves as nonexistent. Some of the patients suggested that this situation was equal to "vanishing as an individual".

"Not being able to speak was like death for me" (H.Y)

"Look at you!', into what you turned. You make noise, nothing happens; you write, nothing happens, ........ (H.K.)

"It seemed strange to me. It was as if a dead lied on teneshir (the bench on which the corpse is washed). I felt it. It hurt me. I was an energetic man, I used to talk a lot. I was liked by everybody around. Therefore, it hurt me a lot not to be able to speak". (K.B.)

Patients reported that they felt themselves hopeless and incapable as they failed to express their thoughts and that this situation caused of them to lose their self-confidence. Also patients explained that they became very happy when they were able to speak again, that they again experienced the joy of living, felt gratitude for this ability and understood that "voice" is a power.

"I was like a child in the time period that I was unable to speak. I lost my self-confidence." (E.B.)

"Sure, there is loss of self confidence. For example, there are some friends talking to each other, communicating but you cannot speak and communicate. Therefore, you experience loss of self-confidence. As if you were isolated or you felt as if your life were gone”. (H.Y.)

What matters in communication is not only speaking to the significant others or health personnel and communicating the needs and getting their help. Communication also represents being as a human. Therefore, a change in the ability to communicate is perceived by the patients as a loss of "their own existence" (Fletcher, Cohen, Schumacher and Lydiatt 2012). Theme 2: Problems caused by inability to speak

It was found out in the study that patients had difficulty expressing physical needs (pain, breathing, nutrition, toilette, etc.) due to the inability to speak; which may cause troubles in determining care and treatment needs of the patients correctly, or patients may get wrong and poor treatments. Besides, there will be problems in understanding whether or not patients approve the treatments. A patient who does not receive the necessary care will have both physiological problems and helplessness.

"It was the night I had laryngectomy. I could not breathe. I opened my eyes, heard no voice. Yes, there were two attendants but I could not make myself heard. I could not breathe and was nearly suffocated... I needed to go to the toilette but I could not even tell this". (H.S.)

Patients also told that they had such negative feelings as anger, helplessness, fury, nervousness, sorry, desperation, disappointment, guilt, regret and fear to speak again because they could not tell their physical, emotional and social needs due to inability to make verbal communication. At the same time; there were those who told that they cried due to helplessness because they could not express themselves.

"Nobody didn't understand me, which makes you angry because I need them. What can I do? I get angry and cry". (H.K)

"I got nervous, I suddenly got angry. First, psychologically you feel devastated and ruined when you cannot talk". (H.Y)

In life, people may lose ability of verbal communication due to various reasons. The sources emphasize that unmet communicational needs will cause negative emotions such as anger, helplessness, hopelessness, frustration and loss; psychical problems such as anxiety, depression and sleep disorders and changes in social relations (Katz, Irish, Devins, Rodin and Gullane 2003). Meanwhile, patients who cannot talk have the feeling of loss of control, desensitization, fear, stress and disappointment (Dickerson, Stone, Panchura and Usiak 2002; Stein-Parbury and McKinley 2000). In our study, it was found out that those who could not communicate had negative feelings such as anger, nervousness, fury, sorrow, disappointment, guilt and helplessness. It was an expected outcome that that patients who could not express themselves suffered from both symptoms caused by the disease and operation (pain, respiratory difficulty, oral nutrition problems) and experienced communication problems and thus had negative feelings. In order to alleviate psychological problems, patients should be given enough time before surgery to talk about their fears and concerns and provide detailed information about the postoperative care process. The communication method in the postoperative period (cards, call bell, pen and paper, blackboards, etc.) should be determined 
prior to surgery. When patients fail to communicate or face difficulties in communication, sufficient time shold be allocated to understand what they really express and need. Furthermore, contact people should repeat after patients and ask them to confirm if correct .

It was found that the inability to speak resulted in social isolation in patients. They stated that they became angry when they failed to express their emotions and that this situation adversely influenced their relationships with their family members and health care professionals. Besides, some of the participants told that they would not welcome visitors because they felt bad, angry and they did not want to be as they were in front of the friends and relatives during the time when they could not communicate.

"Of course, I did not welcome visitors then. I let them look at me at doors because you got angry when you could not talk about things, and I wanted them to go away. You wanted to be alone". (Y.O.)

"Sure, I had many friends who visited me. Sometimes, I felt bad, too. Once, I used to talk to them in a happy way but now I am as quiet as a church mouse and just sit". (K.B.)

"People looked as if I would never become able to speak again. And I ordered away some of them. Therefore, physicians prohibited the entry of any other users into my room because I was extremely emotional." (E.B.)

It was noted that one of the outcomes of inability to make verbal commutation among the participant patients was "social isolation". Similarly, in the study of Fletcher, Cohen, Schumacher and Lydiatt (2012) too, it was found out that patients experienced difficulty being in groups and social isolation as a result of the change in communication. Communication is the indispensible constituent of socialization. People who suffer from loss of communication may be abstain from social settings because they do not interact with others. For Dropkin (2001), resocialization after head and neck surgery includes "exposure of the defect to others," as well as the ability to communicate and "actively interact with others". When the patient tries to tell something, the people around prevent him from speaking or they do not understand him; which may also lead to patient's breaking off the communication with others. Health care workers should be aware of this and try to find solutions to the reasons that put the patients in isolation. In the study of Zeine and Larson (1999); half of the patients who received laryngectomy stated that they were of the opinion that the social changes they underwent should be learnt.

\section{Theme 3: Communication methods}

During the period in which patients cold not talk, they told that they used writing, gestures, facial gestures, acceptance or refusal using lip and head gestures in order to communicate with the significant others. However, of these techniques, they told that the most preferred and used technique was "communication with writing".

"I used to tell my problem first with eyes, hands, but nobody understood. Finally, the kid brought me a small notebook. I communicated my needs by writing on the notebook". (Y.M.)

Although communicating with writing was the most preferred technique, patients did not find it sufficient for communication.

"Well, I expressed myself by writing but I should see them to make sure that they understood me. I hit the side of the bed or dining table so that they looked at me and I would write but they did not see me". (H.K)

"For example; when I needed to tell something urgent or I needed to answer them when they asked me something; I could not answer by writing". (A. H.)

The reason was that writing took time, the writing of the patients was illegible when they wrote fast, patients did not use one arm or used it in a limited way due to parenteral treatment and the patient or the attendant was illiterate. Prevention of hand and arm gestures by parenteral treatment tools and having an urgent need and being too much tried to write make "communication with writing" insufficient. Various visual and auditory communication tools were developed for facilitating communication with these patients and these tools were shown to be effective (Otuzoglu and Karahan 2014; Lorah, Tincani, Dodge, Gilroy, Hickey and Hantula 2013; Rodriguez, Rowe, Koeppel, Thomas, Troche and Paguio 2012; Patak, Gawlinski, Fung, Doering, Berg and Heneman 2006). The use of these tools, which are developed for enabling patients to establish effective communication, should be expanded.

\section{CONCLUSION}

As the ability to speak of those patients who get partial laryngectomy is lost temporarily, the communication problems experienced by this patient group are not addressed much. However, 
it is understood when the data obtained from this study are considered that patients who have partial laryngectomy also experience physical, social and psychological problems just as in the case of those patients who have total laryngectomy or those who are given mechanical ventilation. The data obtained through the study

\section{REFERENCES}

Abendstein H, Nordgren M, Boysen, M, Jannert, M, Silander, E, Ahlner-Elmqvist M, et al. Quality of life and head and neck cancer: A 5 year prospective study. Laryngoscope 2005;115(12):2183-92.

Alasad J, Ahmad M. Communication with critically ill patients. Journal of Advanced Nursing 2005; 50(4): 356-62.

Braun V, Clarke V. Using thematic analysis in psychology. Qualitative Research in Psychology 2006; 3(2): 77-101.

Dickerson S, Stone V, Panchura C, Usiak D J. The meaning of communication: Experiences with augmentative communication devices. Rehabilitation Nursing 2002;27(6): 215- 20.

Dropkin M J. Anxiety, coping strategies, and coping behaviors in patients undergoing head and neck cancer surgery. Cancer Nursing 2001;24(2): 143-8.

Epstein R M, Franks P, Fiscella K, Shields C G, Meldrum S C, Kravitz R l, et al. Measuring patientcentered communication in patient-physician consultations: theoretical and practical issues. Soc Sci Med 2005; 61(7):1516-28.

Evitts P M, Kasapoglu F, Demirci U, Miller JS. Communication adjustment of patients with a laryngectomy in Turkey: analysis by type of surgery and mode of speech. Psychology, Health \& Medicine 2011;16(6): 650-660.

Fletcher B S, Cohen M Z, Schumacher K, Lydiatt W. Blessing and a curse head and neck cancer survivors' experiences. Cancer Nursing 2012;35(2): 126- 32 .

Happ M B, Interpretation of nonvocal behaviors and the meaning of voicelessness in critical care. Soc Sci Med. 2000;50(9):1247-55.

Happ M B, Roesch T, Kagan S H. Communication needs, methods, and perceived voice quality following head and neck surgery. Cancer Nursing 2004;27(1):1-9.

Hebel F, Mantsopoulos K, Bohr C. Assessing quality of life in patients after partial laryngectomy. Hippokratia 2014;18(2):156-61.

Higginbottom G M. Sampling issues in gualitative research. Nurse Researcher. 2004;12(1):7-19.

Howren M B, Christensen A J, Karnell L H, Funk G F. Health-related quality of life in head and neck cancer survivors: impact of pretreatment depressive symptoms. Health Psychol 2010;29(1):65-71.

Katz M R, Irish J C, Devins G M, Rodin G M, Gullane $\mathbf{P}$ J. Psychosocial adjustment in head and neck cancer: the impact of disfigurement, gender and social support. Head and Neck 2003;25(2):103-12. show us that solutions should be produced so that those patients who experience communication problems as a result of partial laryngectomy can establish effective communication. For this purpose, various written and visual communication tools should be developed and the use of such tools should be expanded.

Lorah E R, Tincani M, Dodge J, Gilroy S, Hickey A, Hantula D. Evaluating Picture Exchange and the $\mathrm{iPad}^{\mathrm{TM}}$ as a Speech Generating Device to Teach Communication to Young Children with Autism. J Dev Phys Disabil 2013;25(6):637-49.

Otuzoglu M, Karahan A. Determining the effectiveness of illustrated communication material for communication with intubated patients at an intensive care unit. International Journal of Nursing Practice 2014;20(5): 490-8.

Ozlugedik S, Unal A. Epidemiology and risk factors in head and neck cancers. Contemporary Approaches in Ear, Nose, Throat, Head and Neck Surgeries 2005;1(3): 51-6.

Ozudogru E, Kaya E. Larynx cancer. Galenos Monthly Medicine Journal. 2006;111(9): 38-44.

Patak L, Gawlinski A, Fung NI, Doering L, Berg J, Henneman E A. Communication boards in critical care: Patients' views. Applied Nursing Research 2006;19(4): 182-90.

Philippe Y, Espitalier F, Durand N, Ferron C, Bardet E, Malard O. Partial laryngectomy as salvage surgery after radiotherapy: oncological and functional outcomes and impact on quality of life. A retrospective study of 20 cases. Eur Ann Otorhinolaryngol Head Neck Dis 2014;131(1):15-9.

Rodriguez C S, Rowe M, Koeppel B, Thomas L, Troche M S, Paguio G. Development of a communication intervention to asist hospitalized suddenly speechless patients. Technology and Health Care 2012;20(6): 489-500.

Sammut L, Ward M, Patel N. Physical activity and quality of life in head and neck cancer survivors: A literature review. Int J Sports Med 2014;35(9):794-9.

Semple C J, Dunwoody L, Kernohan W G, McCaughan E. Developmental and evaluation of a problem-focused psychosocial intervention of patients with head and neck cancer. Support Care Cancer 2009;17(4):379-88.

Semple C J, Sullivan K, Dunwoody I, Kernohan W G. Psychosocial interventions for patients with head and neck cancer. Cancer Nursing 2004;27(6):434-41. Singer S, Merbach M, Dietz A, Schwarz R. Psychosocial determinants of successful voice rehabilitation after laryngectomy. J Chin Med Assoc 2007;70(10):407- 23.

Stein-Parbury J, McKinley S S. Patients' experiences of being in an intensive care unit: A select literature review. American Journal of Critical Care 2000;9(1):20- 7 .

Tas A, Yagız R, Karasalihoglu A R, Koten M, Adalı M K, Uzun C. Larenks kanserli hastaların 
Anadolu Hemşirelik ve Sağlık Bilimleri Dergisi, 2016;19:3

cerrahi tedavi sonrası yaşam kalitesinin değerlendirilmesi. K.B.B. İhtisas Dergisi 2004;12(34):84-90.

Uyer G. Nurse and patient communication and the significance of communication for the patients. Journal of Medicine Ethics, Law and History at the Turkish Clinics 2000;8(2):90- 4.

Webster K T, Samlan R A, Jones B, Bunton K, Tufano R P. Supracricoid Partial Laryngectomy: Swallowing, voice, and speech outcomes. Annals of
Otology, Rhinology \& Laryngology 2010;119(1):106.

Yıldırım A, Simsek H. Sosyal Bilimlerde Nitel Araştırma Yöntemleri. 9. Basım. Ankara: Seçkin Yayınevi; 2013, p. 129-44.

Zeine L, Larson M. Pre-and post-operative counseling for laryngectomees and their spouses: An Update. Journal of Communication Disorders 1999; 32(1):51-61. 